\title{
Lymphadenopathy associated with cat-scratch disease in a child
}

\author{
Guifeng Chen MD, Zhongjie Li MD, Guodong Ding PhD
}

Cite as: CMAJ 2021 June 21;193:E962. doi: 10.1503/cmaj.202663

A

10-year-old boy was referred to the department of pediatrics with a 10-day history of increasing pain and swelling of the right elbow and intermittent low-grade fever. He had no other constitutional symptoms, such as weight loss, night sweats or malaise, and his symptoms had not improved with oral antibiotic therapy using cefprozil $(15 \mathrm{mg} / \mathrm{kg} / \mathrm{d}$, twice daily for 6 consecutive days). The child reported that a stray kitten had bitten his right index finger 4 weeks earlier, leaving a $0.5 \mathrm{~cm}$ residual lesion. His right supratrochlear and epitrochlear lymph nodes were enlarged and tender, and he had smaller tender nodes in the ipsilateral axilla. We did not observe any hepatosplenomegaly or other lymphadenopathy. Ultrasonograms of the right upper arm and axillae showed well-defined, echogenic, hyperemic solid masses with prominent vascular pedicles, typical of enlarged lymph nodes (Figure 1 and Appendix 1, available at www.cmaj.ca/lookup/doi/10.1503/ cmaj.202663/tab-related-content). Serological test results for Epstein-Barr virus, cytomegalovirus, adenovirus, mycoplasma, toxoplasmosis, syphilis and HIV were negative. Metagenomic nextgeneration sequencing analysis from a whole blood sample showed Bartonella henselae infection. The patient could not tolerate oral azithromycin, so we treated him with intravenous azithromycin $(10 \mathrm{mg} / \mathrm{kg} / \mathrm{d}$, once daily) for 7 days. The patient's fever rapidly resolved and his lymph nodes progressively decreased in size. He remained well and reported no other symptoms at regular follow-ups.

Cat-scratch disease, a worldwide zoonosis caused by the gram-negative bacteria $B$. henselae, is characterized by a benign, self-limiting regional lymphadenopathy that develops 1-8 weeks after a domestic feline scratch or bite..$^{1,2}$ About 22000 cases of catscratch disease are diagnosed annually in the United States, predominately in children. ${ }^{3,4}$ It is not a public health notifiable disease. Antibiotics are not suggested for mild presentations, but

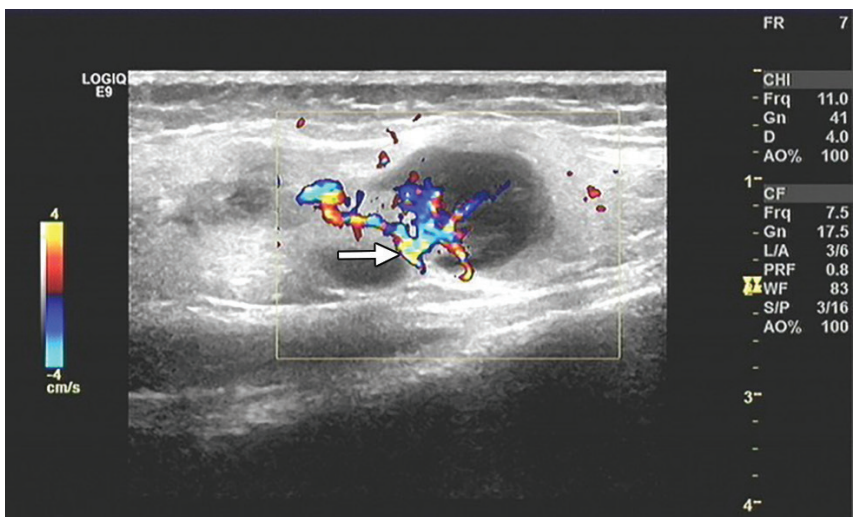

Figure 1: Doppler ultrasonagram of a 10-year-old boy's right upper arm, showing well-defined, echogenic, hyperemic solid masses, with prominent vascular pedicles (arrow) typical of enlarged supratrochlear lymph nodes. The largest mass measured $2.4 \times 1.5 \mathrm{~cm}$.

expert opinion supports the use of azithromycin for those with moderate disease and in immunocompromised patients. ${ }^{4,5}$ Physicians should consider cat-scratch disease in their differential diagnosis of regional or unilateral lymphadenopathy.

\section{References}

1. Eidlitz-Markus T, Zeharia A. Images in clinical medicine. Cat scratch disease lymphadenopathy. N Engl J Med 2006;354:e17.

2. Rohr A, Saettele MR, Patel SA, et al. Spectrum of radiological manifestations of paediatric cat-scratch disease. Pediatr Radiol 2012;42:1380-4.

3. Barson WJ, Honegger JR, Texter K. Acute myopericarditis associated with cat scratch disease in an adolescent. Pediatr Infect Dis J 2014;33:982-4.

4. Nelson CA, Moore AR, Perea AE, et al. Cat scratch disease: U.S. clinicians experience and knowledge. Zoonoses Public Health 2018;65:67-73.

5. Rolain JM, Brouqui P, Koehler JE, et al. Recommendations for treatment of human infections caused by Bartonella species. Antimicrob Agents Chemother 2004;48:1921-33

\section{Competing interests: None declared.}

This article has been peer reviewed.

The authors have obtained parental consent.

Affiliations: Department of Pediatrics (Chen, Li), Jiashan No.1 People's Hospital, Jiashan, Zhejiang, China; Department of Respiratory Medicine (Ding), Shanghai Children's Hospital, Shanghai Jiao Tong University, Shanghai, China
Content licence: This is an Open Access article distributed in accordance with the terms of the Creative Commons Attribution (CC BY-NC-ND 4.0) licence, which permits use, distribution and reproduction in any medium, provided that the original publication is properly cited, the use is noncommercial (i.e., research or educational use), and no modifications or adaptations are made. See: https://creativecommons.org/licenses/by-nc-nd/4.0/

Acknowledgement: The authors thank Dr. Angela Vinturache for her critical comments and substantial revision of this report.

Correspondence to: Guodong Ding, dingguodong@shchildren.com.cn 